ECONOMY

\title{
THE IMPORTANCE OF THE CONVERGENCE OF INTERNATIONAL ACCOUNTING STANDARDS TO THE NATIONAL ACCOUNTING SYSTEM OF UZBEKISTAN
}

\author{
Ergasheva Shahlo Turgunovna ${ }^{1}$ \\ Shermatov Behzod Xalimkul o'g'li ${ }^{1,2,3}$. \\ ${ }^{I}$ Tashkent State University of Economics, Uzbekistan. \\ ${ }^{2}$ Private company Financial Advisory and Tax Consultants Group, Tashkent, Uzbekistan. \\ ${ }^{3}$ Tashkent State University of Juridical, Tashkent, Uzbekistan.
}

DOI: https://doi.org/ 10.31435/rsglobal_ws/31012019/6301

\section{ARTICLE INFO}

Received: 19 November 2018

Accepted: 25 January 2019

Published: 31 January 2019

\section{KEYWORDS}

NAS - National Accounting Standards of Uzbekistan, CPD programs - Continuing Professional Development programs, IFRS International Financial Reporting Standards, NSA - National Standards of Audit of Uzbekistan, ISA -

International Standards of Audit, CAP

- Certified Accounting Practitioner,

CIPA - Certified International

Professional Accountant.

\begin{abstract}
The actuality of the research:

-Economic integration

-Comparability \& uniformity of financial statements

-Attracting potential foreign investors.

-The requirement of the world financial markets \& stock exchanges.

-The decreasing of costs of learning local standards.

-The aim of research are:

-Carrying out the improvement of our accounting systems to speed up the development of our country with the help of foreign investors' capital.

Developing our national accounting standards based on international financial reporting standards and to reveal the problems associated with this.
\end{abstract}

Citation: Ergasheva Shahlo Turgunovna, Shermatov Behzod Xalimkul o'g'li. (2019) The Importance of the Convergence of International Accounting Standards to the National Accounting System of Uzbekistan. World Science. 1(41), Vol.2. doi: 10.31435/rsglobal_ws/31012019/6301

Copyright: (C) 2019 Ergasheva Shahlo Turgunovna, Shermatov Behzod Xalimkul o'g'li. This is an open-access article distributed under the terms of the Creative Commons Attribution License (CC BY). The use, distribution or reproduction in other forums is permitted, provided the original author(s) or licensor are credited and that the original publication in this journal is cited, in accordance with accepted academic practice. No use, distribution or reproduction is permitted which does not comply with these terms.

Introduction. Nowadays, the world is changing very quickly and so is Accounting Practices. As free movement of capital and other resources is very important for the economic and political integration of the countries, harmonization and convergence of accounting and financial reporting can be considered as an integral part of this development. Furthermore, shareholders and other stakeholders can be better able to compare financial information of different firms around the world, which can be hardly achieved by different accounting and financial reporting practices. The creation of a more apparent and efficient capital market that will assist a lower cost of capital. That is why the convergence of international accounting standards to the national accounting system has already become an issue, need and problem in Uzbekistan.

When market economy is adopted instead of planned, there occurred the need for infrastructure related to the development of this system, and it is gradually improving after gaining independence.

The development and problems in the field of accounting also can be seen in the market economy. The need of conducting all organizations' accounting based on uniform standards is 
increasing around the world day by day. This is one of the main ways for attracting the large-scale flow of capital and maximizing profits.

Research results. Now let us look through different triggers turn by turn in order to understand better the real need and problem of converging international accounting standards to the national accounting system.

Firstly, large foreign investors who have lots of capital try to increase their capital and want to invest to a safely business. Then, they begin searching for profitable organizations that have enough property and good history of doing business. Having found several of them, potential investors compare their financial situation and try to choose the best of them. Financial data and indicators in the statements allow of carrying out this comparison, only if they are prepared in the same manner. It is possibly only according to financial statements prepared in accordance with international financial reporting standards.

Secondly, the financial statements prepared in accordance with international financial reporting standards will decrease the costs associated with the learning of local standards. Not only investors, but also everybody does not like to spend extra money.

Thirdly, financial statements of companies must be prepared in accordance with international financial reporting standards to have access to an international financial market and to sell their securities there.

Fourthly, the transition to international accounting standards or converging of national accounting standards encourages foreign investors begin their business in our country.

Based on the above, it can be said that the preparation of financial statements in accordance with international financial reporting standards helps to attract the capital of investors indeed.

Harmonization of accounting processes in the world and spread of IFRS rules around the world make the IFRS-based company and all its stakeholders feel confident about future prosperity of the company. The role of transparent standards have been improving forecast accuracy, financial and technical support, and market liquidity, and reducing the private information held by the owners of the company and reflecting share prices well. Additionally, the process enhances investments and prospers securities markets.

Our country should maintain continuous support for the harmonization process by improving internal co-ordination within its. The need for harmonization is comprehensible, and beneficial for the countries at large born by commitments and efforts of regulators, standard setters, financiers, business community, the public and the accountancy profession.

Conclusions. We made major recommendations in four specific areas:

Statutory Framework. We recommend that the Uzbek statutory and legal framework be amended to:

- Define criteria for distinguishing between public interest entities (PIEs), small and medium sized enterprises (SMEs), and micro entities for tailoring proportionate financial reporting requirements appropriate to the needs of the market and the entities' own information needs.

- Strengthen the oversight system of the audit profession and create a robust audit quality assurance review program.

Public Availability of Financial Statements. Measures to strengthen the enforcement of corporate financial reporting requirements include:

- Requiring all entities subject to regulation (e.g., financial institutions, insurance companies, etc.) to submit full financial statements (which would include all notes to the financial statements in compliance with NAS 1) to their appropriate regulator. Each regulatory agency should publish these financial statements in full on their websites, thus implementing the current legal requirement that company financial statements be made publicly available. Currently, companies release only a summarized balance sheet and income statement rather than a complete set of financial statements, attaching to them the audit report on full financial statements.

- Over the longer term, the Ministry of Finance may wish to consider creating a registry where the financial statements of all companies subject to financial statement requirements would be centrally filed and made publicly available.

- The continued validity and, where applicable, renewal of audit certificates and licenses for both audit firms and individuals should be contingent on submitting evidence of compliance with applicable legal requirements, e.g., continuing professional development, indemnity insurance, etc. The Ministry of Finance should reconsider the current requirement that auditors retake their qualification examinations every five years, which appears rather onerous. 
- In addition, the Ministry of Finance should explore the possibility of amending relevant legislation so that professionals auditing and accounting associations hoping to establish themselves in Uzbekistan would first have to obtain the Ministry of Finance license or authorization after they have met certain, specified criteria. As well, membership in a recognized association should be mandatory for auditors and audit firms. This would be the beginning of a more robust and effective audit quality control system.

Institutional Capacity Building. All regulators and other institutions with responsibilities in the field of financial reporting face increasing challenges as the changing business environment creates demand for an updated accounting and auditing infrastructure. Although the cautious approach to accounting reform did not result in a critical need for institutional strengthening, there is a need for increased capacity, as evidenced by, for example, the fact that the disclosure requirements listed in NAS 1 are not enforced and that the absence of these disclosures does not always result in a modified audit opinion. This indicates a need to strengthen the capacity of both auditors and the audit quality control function. Accordingly, it is recommended that:

- The regulators receive support, including from international peer institutions, to build their capacity in terms of the number, qualification levels, and training of their staff.

- The professional organizations of accountants and auditors should receive similar support, so that they can increase their capacity to regulate their members more effectively, particularly in the area of audit quality control and ethics.

Professional Education and Training. While the education system appears to turn out sufficient numbers of future professionals, there is a need to strengthen the capacity of accounting and auditing education at universities and to build continuity between university and pre-professional education programs, as well as further expansion of existing CPD programs. The proper understanding and application of international accounting and auditing standards and requirements requires a solid foundation of education and training for financial statement preparers, auditors, and regulators. To accomplish this, the following actions are recommended:

- To meet the increasing needs of the Uzbek economy requires greater capacity in the current providers of education and training in accountancy. This, in turn, calls for the introduction of new programs to update the skills of university professors in contemporary accounting and auditing techniques, which they can then transfer to their students. Alternatively, secondment of accounting faculty members in Uzbekistan to other universities in the region and/or bringing in professors from other former Soviet republics which have already made the necessary changes in curriculum could be considered.

- University curricula may need a comprehensive overhaul to cover, in addition to NAS, also IFRS, as well as the principles and theory of accounting underpinning both NAS and IFRS. Similar consideration should be given to auditing theory and principles underpinning NSA and ISA. Support should be provided particularly to those institutions that strive to create high-quality programs using their own resources.

- Emphasis should be placed on better integration of professional certification and licensing requirements and university programs, e.g., aligning university and CAP/CIPA courses so that university graduates are granted exemptions from certain CAP/CIPA examination requirements. The profession and education providers should also align their CPD training courses.

The recommendations above require a holistic, multi-disciplinary approach and should be implemented gradually following the publication of this report. Their implementation will require he cooperation of a wide range of stakeholders, including the government, regulators and the accountancy profession, and should be championed by a senior government figure with sound political support. In addition, input from peer countries may present our country - the Republic of Uzbekistan with unique insights into how similar challenges have been addressed in similar countries.

Our country should create a working body comprised of representatives of the various stakeholder groups to advise policymakers and regulators on how to best implement the recommendations. The plan should include a comprehensive budget indicating the resources necessary for successful implementation. Government, stakeholders and development partners should work together to secure those resources to achieve the common goal of enhancing the quality and availability of financial information in our country.

\section{REFERENCES}

1. Закон Республики Узбекистан «О бухгалтерском учете» от 13 апрель 2016 г. (с последующими дополнениями и изменениями).

2. «Налоговый кодекс» Республики Узбекистан от 25 декабря 2007 г. № ЗРУ - 136 (с последующими дополнениями и изменениями). 
3. Decree of President Islam Karimov of Uzbekistan about "On measures on introduction of modern methods of corporate management in joint stock companies" on 24 April 2015.

4. The decision of the President of the Republic of Uzbekistan. On priority directions of further reforming and increasing sustainability of financial-banking system of the republic in 2011-2015 and achieving high international rating indicators. Collection of Laws of the Republic of Uzbekistan, 2010.

5. «О дополнительных мерах по стимулированию развития микрофирм и малых предприятий» от 20 июня 2005 г. №УП-3620, Собрание законодательства Республики Узбекистан, №25-26 (161-162) июнь 2005 г.

6. «О либерализации финансовой отчетности субъектов предпринимательства за хозяйственные правонарушения» от 24 июня 2005 г. № УП-3622, Собрание законодательства Республики Узбекистан, № 25-26 (161-162) июнь 2005 г.

7. Национальные стандарты бухгалтерского учета Республики Узбекистан. Издано в издательскоинформационном центре Национальной Ассоциации бухгалтеров и аудиторов. -Т.:2012 г.

8. Закон Республики Узбекистан «Об акционерных обществах и защите прав акционеров» от 26.04.1996 г. (с последующими дополнениями и изменениями).

9. Ball, R., Robin, A., and Wu, J. (2003). Incentives versus standards: properties of accounting income in four East Asian countries and implications for the acceptance of IAS. Journal of Accounting and Economics, 36, 235-270.

10. Brown, P. (2011). International Financial Reporting Standards: How real are the benefits? Accounting and Business Research, 41(3), 269-285 p.

11. Choi, F., Frost C., Gary, K. (2002). International Accounting.4 ${ }^{\text {th }}$ edition. New Jersey: Prentice Hall, $243-$ 296.

12. DeFond, M., Hu, X., Hung, M., and Li, S. (2011). The impact of mandatory IFRS adoption on foreign mutual fund ownership: The role of comparability. Journal of Accounting and Economics, 51(3), 242-256.

13. Deloitte \& Touche. (2003). IFRS: Of Growing Importance for US Companies. Retrieved on December 1, 2008.

14. International Business \& Economics Research Journal (2010). IFRS Adoption in the EU, Accounting Harmonization and Markets Efficiency: A Review by Gabriele Guggiola, University of Insubria, Varese, Italy Vol. 9, No. 12.

15. Jermakowicz, E. (2004). Effects of Adoption of International Financial Reporting Standards in Belgium: The Evidence from BEL-20 Companies. International Business Research, pp. 198-199.

16. McLeay, S., Neal, D., and Tollington, T., (1999). International Standardization and Harmonization: A New Measurement Technique. Journal of International Financial Management and Accounting, Vol. 10, No. 1, pp. 42-70.

17. Narayan, F.\& Reid, B. (2000). Financial Management and Governance Issues in the Republic of Uzbekistan. Asian Development Bank. Retrieved on January 2, 2009.

18. REPORT ON THE OBSERVANCE OF STANDARDS AND CODES (ROSC), The Republic of Uzbekistan, ACCOUNTING AND AUDITING, December 2008, made by team from World Bank, 38-76 p.

19. Samir, M. S. (2003). Harmonization of Accounting Standards. Chartered Accountant, ICAI

20. Shima, K. M., \& Gordon, E. A. (2011). IFRS and the regulatory environment: The case of U.S. investor allocation choice. Journal of Accounting and Public Policy, 30(5), 481-500.

21. Turner, L. (2001). Disclosure and Accounting in a Global Market: Looking to the Future. 35-56 p.

22. Сейдахметов Л.Д. Международная стандартизация и гармонизация учета и отчетности. А., 2006.

23. http://www.icar.ru - International Center of Accounting Reforms (ICAR)

24. http://www.gaap.ru - The information center of theory and practice of financial accounting

25. http://www.ifrs.org/Pages/default.aspx - International Accounting Standards Board and IFRS Foundation

26. http://www.iasc.org.uk - International Accounting Standards Committee (IASC)

27. http://www.fasb.org - Federal Accounting Standard Board USA (FASB)

28. http://www.ifac.org/ - International Federation of Accountants (IFAC)

29. http://www.accaglobal.com/home/ - Association of Chartered Certified Accountants (ACCA)

30. http://www.iosco.org/about/ - The International Organization of Securities Commissions

31. http://www.gaap.ru/biblio/gaapias/strategi/ - Разработка стратегии поддержки российских предприятий при их переходе на МСФО

32. http://www.lex.uz/ - NATIONAL DATABASE OF LEGISLATION UZBEKISTAN (LexUz) 